\title{
PEMAKAIAN MEDICAL RAPID PROTOTYPING UNTUK PREKONTUR PLAT REKONSTRUKSI PADA RESEKSI MANDIBULA
}

\author{
Arya Kusuma Agraha*, Masykur Rahmat**, Rahardjo ${ }^{* * *}$
}

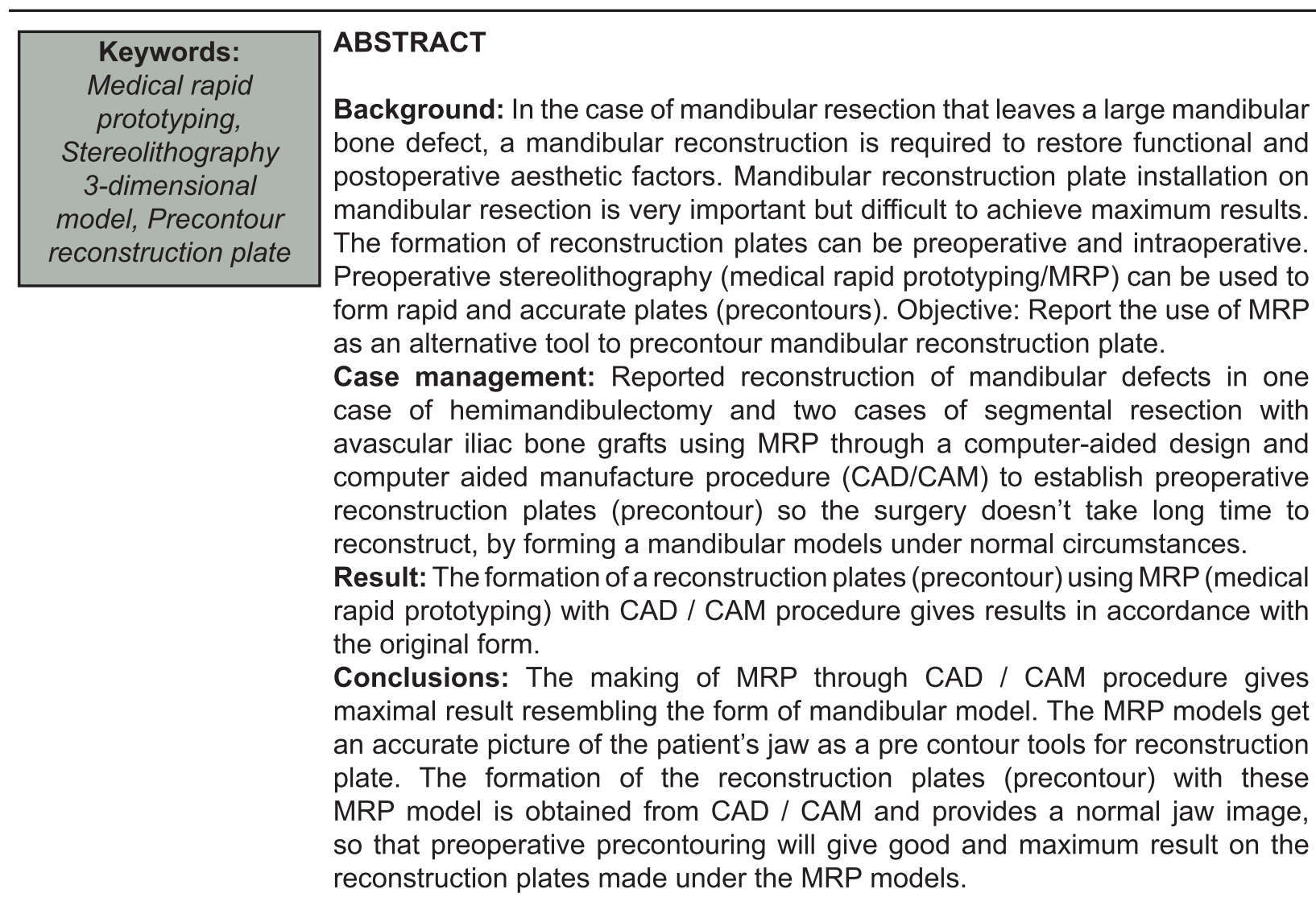

\section{PENDAHULUAN}

Defek mandibula pasca reseksi mandibula memiliki efek dramatis pada struktur anatomi, cara berbicara, deglutinasi, kepercayaan diri dan kualitas hidup pasien ${ }^{1}$. Penanganan defek mandibula pasien pasca reseksi tumor dalam mengembalikan fungsi, artikulasi dan estetika pasien pasca reseksi mandibula dilakukan dengan rekonstruksi mandibula menggunakan plat rekonstruksi ${ }^{2}$. Plat rekonstruksi digunakan untuk menjembatani defek pasca reseksi, biasanya dikombinasikan dengan pemasangan graft tulang ${ }^{3}$. Rekonstruksi pasca reseksi tumor mandibula merupakan hal yang menantang bagi dokter bedah mulut dan maksillofasial karena bentuk geometri mandibula yang kompleks, otot-otot yang berikatan pada mandibula beraksi di area yang berbeda - beda, dan oklusi ${ }^{4,5}$.

Pembentukan plat yang baik adalah hal yang penting untuk mendapatkan stabilitas segmen, posisi spasia yang baik, dan oklusi, setelah ablasi tumor ${ }^{1}$. Pembentukan plat rekonstruksi selama prosedur bedah merupakan pekerjaan yang menjemukan

\footnotetext{
* Residen Program Studi Bedah Mulut dan Maksilofasial, Fakultas Kedokteran Gigi, Universitas Gadjah Mada, Yogyakarta, Indonesia, ${ }^{* *}$ Kepala Poli Bedah Mulut RSUP Dr. Sardjito, Yogyakarta, Indonesia, *** Staf Pengajar Bagian Bedah Mulut dan Maksilofasial Fakultas Kedokteran Gigi, Universitas Gadjah Mada, Yogyakarta, Indonesia Korespondensi: drg.aryakusumaagraha@mail.ugm.ac.id
} 
${ }^{3}$. Sering dilakukan dengan metode "trial and error" menggunakan bent template. Prekontur plat rekonstruksi berulang - ulang dapat merusak bahan metal yang beresiko menjadi fraktur plat prematur, membutuhkan pembukaan bedah yang luas, meningkatkan waktu operasi sehingga terkadang konsentrasi operator hilang, beresiko terjadi kehilangan cairan dan darah yang banyak pada pasien serta meningkatkan resiko infeksi $1,2,6$

Prosedur ini dapat di optimalkan secara signifikan dengan penggunaan model anatomis 3 dimensi. Metode ini sangat membantu rencana pembedahan dan menurunkan waktu operasi. Model seperti ini dikenal sebagai rapid prototyping4. Medical rapid prototyping (MRP) diartikan sebagai model fisik anatomi manusia dengan dimensi yang akurat karena sumber data konstruksi model ini adalah hasil CT scan dengan resolusi tinggi (highresolution computed tomography) ${ }^{1}$. Model dari MRP, dibuat dengan prosedur computeraided design and computer aided manufacture (CAD/CAM) yang memungkinkan untuk manipulasi data digital dan untuk membangun kontur yang dibutuhkan ${ }^{3,5}$. Meskipun terdapat banyak teknologi rapid protyping, yang paling sering digunakan untuk aplikasi dibidang kesehatan adalah stereolithography (STL) model 3 dimensi ${ }^{4,7}$. Penggunaan model stereolithography dapat digunakan pada kasus rekonstruksi mandibula saat perluasan tumor telah menyebabkan kerusakan tulang yang luas membantu prekontur adaptasi plat preoperative ${ }^{3,7}$

Penggunaan stereolithography model 3 dimensi sebagai alternatif prekontur plat rekonstruksi mandibula preoperatif 1,5 : Indikasi : Rekonstruksi dimana kerusakan kontinuitas mandibula oleh karena tumor atau trauma yang luas dan pembentukan plat yang kompleks

Kontraindikasi: Model stereolithography tidak akurat jika terdapat pecahan atau objek asing pada daerah tersebut yang menyebabkan munculnya artefak

Kelebihan :

- Waktu pembedahan singkat

- Adaptasi plat rekonstruksi sangat baik.

- Menurunkan gap/celah plat dengan tulang sehat yang akhirnya menurunkan pembentukan scar juga.

- Mengurangi resiko kelelahan metal (metal fatigue) secara signifikan.

- Meningkatkan dampak yang baik kepasien mengenai diagnosis penyakitnya, memudahkan edukasi pada pasien, dan memperjelas metode rencana pembedahan.

- Berguna sebagai alat bantu mengajar pada kegiatan akademik.

Kekurangan :

- Meningkatkan radiasi pada pasien karena diperlukannya pengambilan CT scan resolusi tinggi.

- Memerlukan biaya tambahan

- Menambah waktu tunggu dari saat diagnosis hingga waktu pembedahan yang sebenarnya oleh karena adanya tahapan tambahan dalam rencana pembedahan.

\section{METODE}

Kami melakukan rekonstruksi pada tindakan satu kasus hemimandibulektomi dan dua kasus reseksi segmental dengan graft tulang illiaka avaskuler pada mandibula di RSUP Dr.Sardjito. Diagnosa sebelum dilakukan reseksi bedah dari semua kasus adalah ameloblastoma. Saat pasien melakukan foto 
CT scan resolusi tinggi, pasien tidak boleh bergerak untuk meminimalkan terjadinya artefak sehingga tercipta model anatomi yang akurat. Data hasil foto CT scan kami simpan ke media yang mudah untuk dipindahkan, selanjutnya kami kirimkan ke Laboratorium desain dan perancangan produk fakultas tehnik mesin dan industri Universitas Gadjah Mada untuk perencanaan teknik virtual dengan prosedur CAD (computer-aided design).

\section{Perencanaan Teknik Virtual}

Kami menggunakan software yang sesuai untuk set data DICOM (digital imaging and communication in medicine). Rencana virtual untuk ke tiga kasus ini berbeda - beda. Hal ini untuk memudahkan analisis rencana preoperatif.

- Kasus 1. Setelah data file CT scan di masukkan ke software yang seusai, data file dari CT scan (gambar 1) diproses menjadi file stereolithography dan dilanjutkan untuk pencetakan stereolithography model 3 dimensi (gambar 2). Selanjutnya mengunakan metode mirroring dimanasisi kiri yang tidak rusak dengan manipulasi di segmentasikan lalu direfleksikan dan disesuaikan kesejajarannya pada sisi yang rusak, data file diproses menjadi file stereolithography dan dicetak menjadi model stereolithography 3 dimensi sebagai neomandibula (Gambar 3).

- Kasus 2. Menggunakan metode autosegmentasi CT scan. Ukuran mandibula yang akan direseksi ditentukan secara virtual. Oleh karena reseksi yang luas dari korpus mandibula dextra hingga korpus mandibula sinistra, mirroring bukanlah pilihan dari rencana virtual pada kasus ini. Neomandibula dibuat dengan mengkombinasikan struktur tulang yang masih tersisa dengan autosegmentasi yang disesuaikan lengkung rahang atas dan tulang rahang bawah yang tersisa, kemudian dibentuk dengan ideal secara virtual. Hal ini dilakukan karena kerusakan oleh tumor melibatkan daerah korpus mandibula bilateral dan tulang mandibula regio anterior.

- Kasus 3. Pada kasus ini neomandibula diperoleh dengan metode mirroring untuk transposisi letak tumor. Tumor terletak pada corpus mandibula dextra dan direfleksikan secara virtual ke sisi corpus mandibula sinistra.

Kasus - kasus yang kami tangani dengan perencanaan rekonstruksi secara virtual :

Kasus 1

Pasien wanita, usia 17 tahun dengan keluhan pembengkakan pada rahang bawah kanan dan benjolan pada gusi rahang bawah kanan yang besar serta kesulitan untuk makan karena gigi pada regio tersebut goyang. Hasil pemeriksaan menunjukkan gambaran ameloblastoma. Kami rencanakan reseksi hemimandibulektomi mandibula dextra. Selanjutnya model stereolithography 3 dimensi neomandibula (gambar 3) ini dilakukan pencetakan menggunakan alginat dan dibuat salinan dengan gips biru (gambar 4). Pada cetakan gips biru pada daerah yang terkena tumor, dilakukan pengurangan gips sebanyak \pm $1 \mathrm{~cm}$ pada regio bukal (lebar mandibula normal pada model stereolithography model 3 dimensi darilingual-bukal $\pm 1,5 \mathrm{~cm}$ ) lebartersisa $\pm 0,5 \mathrm{~cm}$. Tebal plat rekonstruksi yang digunakan adalah $3 \mathrm{~mm}$ (gambar 4). Selanjutnya pengukuran jarak vertikal dari insisal molar pertama rahang atas dextra ke ujung margo inferior mandibula sisi dextra didapatkan $3,5 \mathrm{~cm}$. Adaptasi plat 


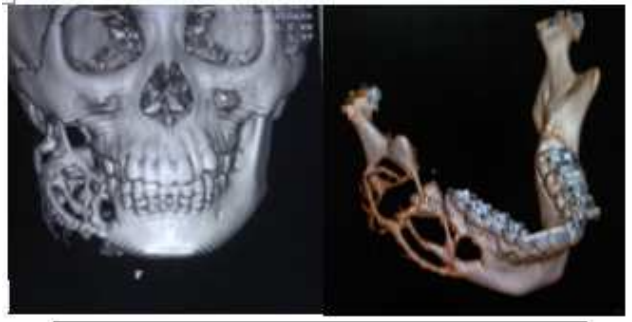

Gambar 1. Foto CT scan resolusi tinggi (kasus 1)

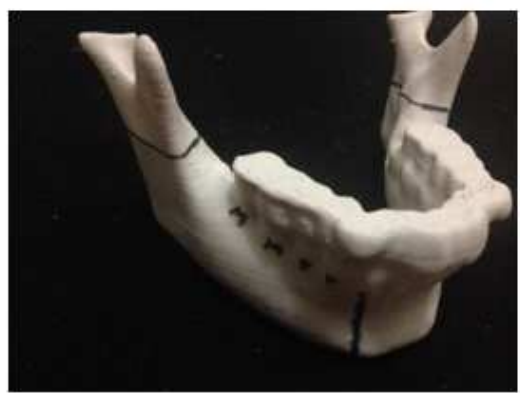

Gambar 3. Model neomandibula dengan prosedur $\mathrm{CAD} / \mathrm{CAM}$ (kasus 1)

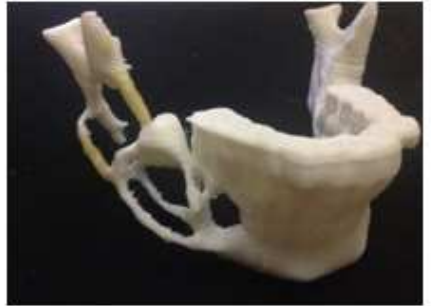

Gambar 2. Model stereolithography 3 dimensi (kasus

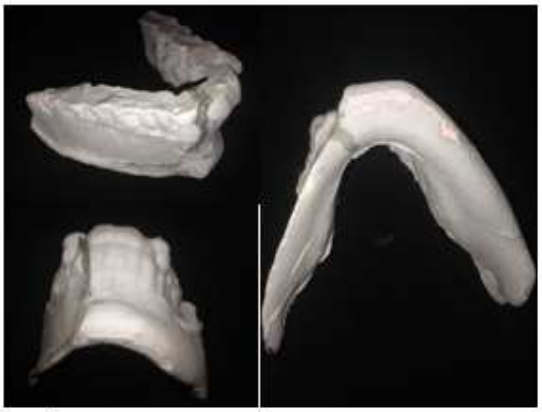

Gambar 4. Cetakan gips salinan dari neomandibula (kasus 1)

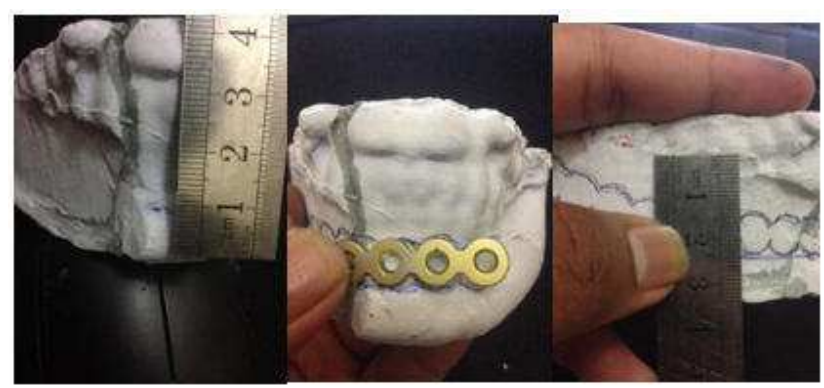

Gambar 5. Rencana preoperatif Posisi plat rekosntruksi $1 \mathrm{~cm}$ diatas margo inferior (kasus 1)
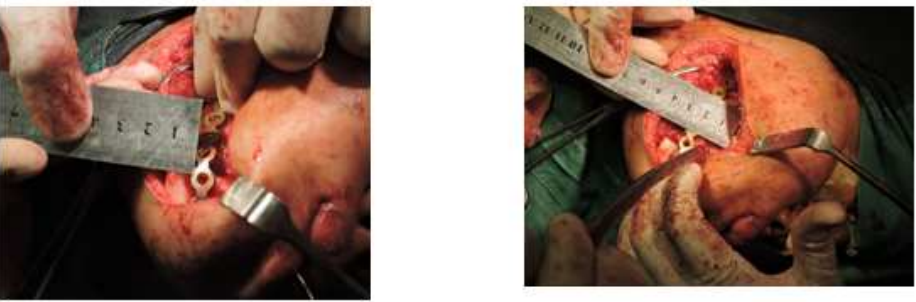

Gambar 6. Peletakkan plat rekonstruksi $1 \mathrm{~cm}$ diatas margo inferior intraoperatif (kasus 1)

Gambar 7. Kontrol peletakkan plat rekonstruksi regio posterior (kasus 1)

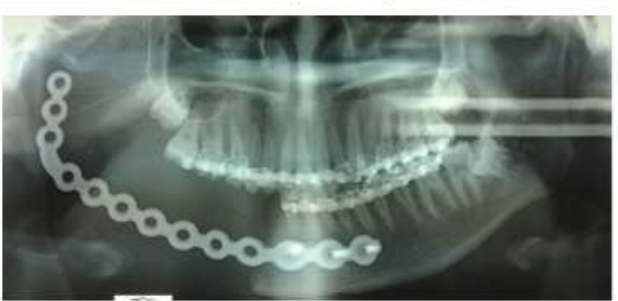

Gambar 8. Foto panoramik Posisi plat rekonstruksi yang adekuat (kasus 1) 


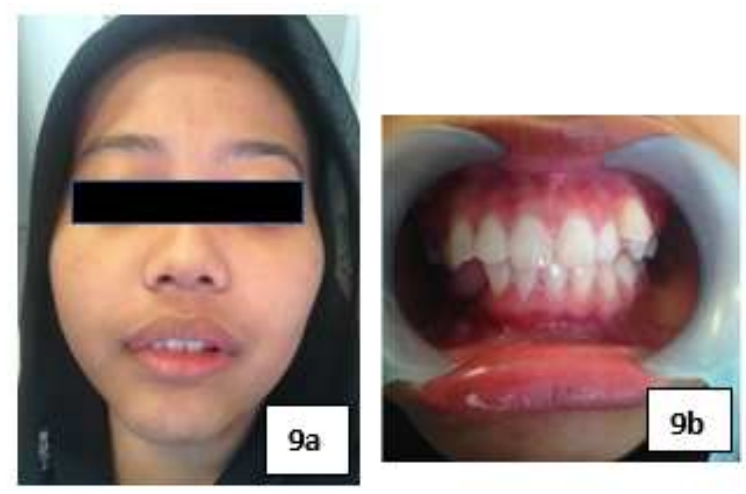

Gambar 9. Pemeriksaan klinis Ekstra oral (a) dan Intra oral (b) post operasi 8 bulan

rekonstruksi kami rencanakan dengan posisi plat rekosntruksi $1 \mathrm{~cm}$ diatas margo inferior (gambar 5) dan dihubungkan dengan garis. Prekontur plat rekonstruksi diadaptasikan mengikuti garis penghubung dari anterior ke posterior. Hal ini dilakukan untuk menghindari penonjolan plat rekonstruksi, yang dapat menjadi komplikasi seperti dehisensi dan tahapan ini juga membantu dalam memastikan letak plat rekonstruksi sesuai plat rekonstruksi prekontur intraoperatif (Gambar 6 dan gambar 7). Operasi berlangsung cepat sekitar 4 jam tanpa adanya komplikasi intraoperatif. Foto panoramik postoperasi menunujukkan posisi plat rekonstruksi adekuat (Gambar 8) dan hasil pemeriksaan klinis ekstra oral dan intra oral post operasi cukup memuaskan (Gambar 9a dan 9b).

\section{Kasus 2}

Seorang laki - laki umur 45 tahun dengan keluhan pembengkakan pada gusi dan rahang sebelah kanan. Pada pemeriksaan radiologis foto panoramik dan 3D CT scan tampak lesi

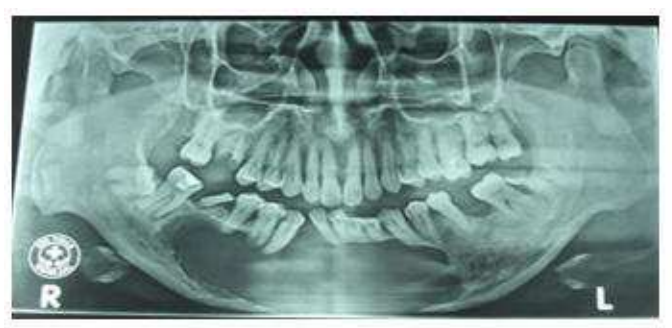

Gambar 10. Foto panoramik (kasus 2)

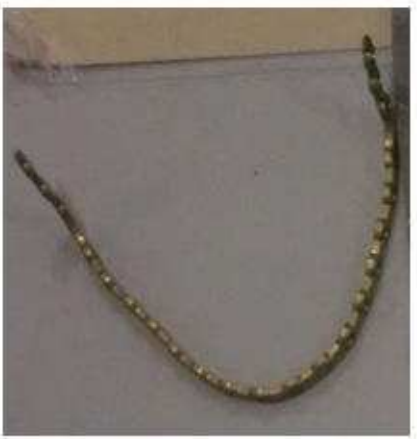

Gambar 12. Plat prekontur (kasus 2)

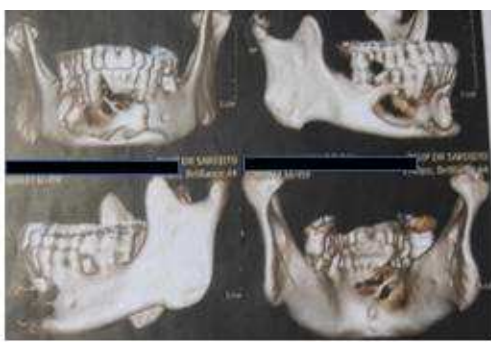

Gambar 11. Foto CT scan (kasus 2)

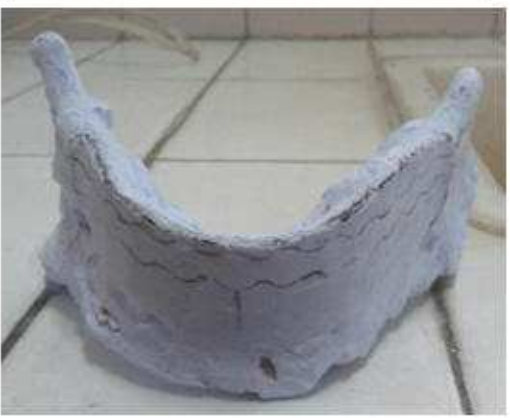

Gambar 13. Salinan neomandibula (kasus 2) 

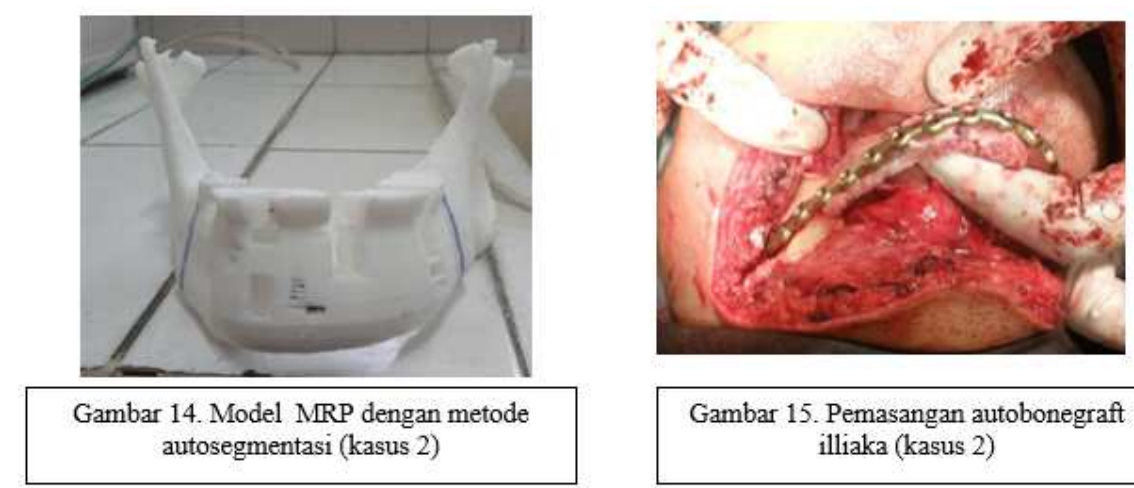

Gambar 15. Pemasangan autobonegraft illiaka (kasus 2)

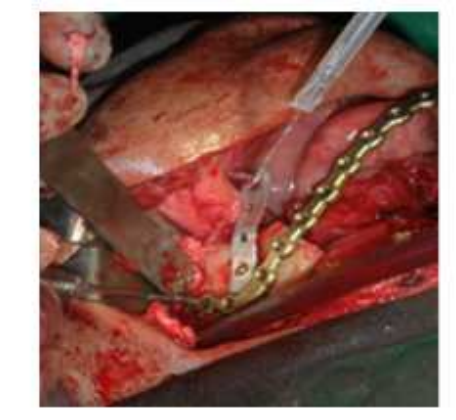

Gambar 16. Coens ramus fixator pada ramus mandibula (kasus 2)

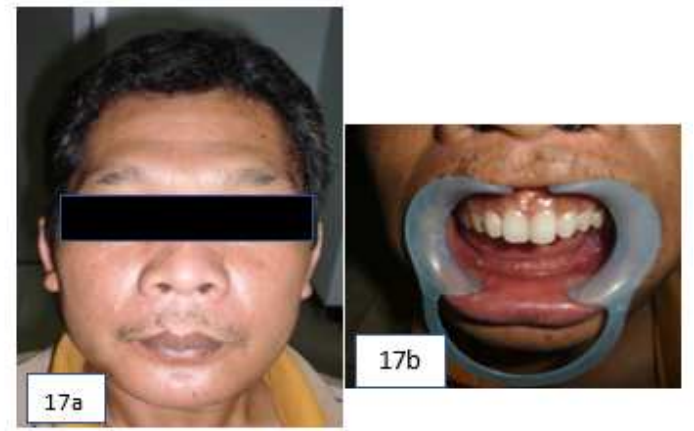

Gambar 17. Pemeriksaan klinis ekstra oral (a) dan intra oral (b) (kasus 2)

Pada kontrol pemeriksaan klinis post operasi didapatkan wajah simetris dan penyembuhan luka intra oral yang baik (gambar 17).

\section{Kasus 3}

Seorang wanita 18 tahun datang dengan keluhan asimetri wajah karena pembengkakan pada rahang bawah kanan (Gambar 18). Pemeriksaan CT scan menunjukkan area radiolusen mulai 44 - 47 (gambar 19). Pada pemeriksaan biopsi menunjukkan ameloblastoma tipe solid. Direncanakan reseksi segmental mandibula dextra dari regio 32 hingga ramus mandibula dextra dengan menggunakan plat rekonstruksi titanium yang telah dilakukan prekontur sebelum operasi (Gambar 20), dengan alat bantu MRP transposisi letak tumor (gambar 21) dan autobone graft avaskuler tulang illiaka (Gambar 22). Pada intraoperatif kami menggunakan 


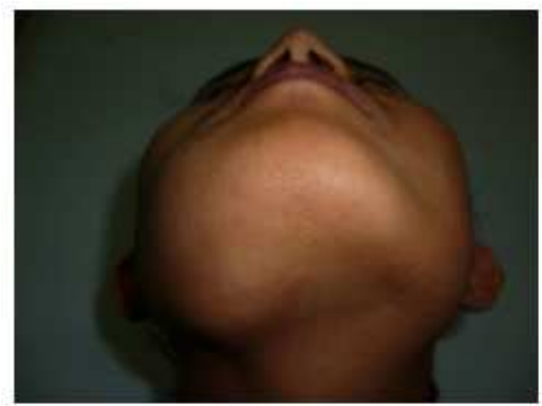

Gambar 18. Pemeriksaan klinis EO tampak asimetri wajah pembengkakan mandibula dextra (kasus 3)

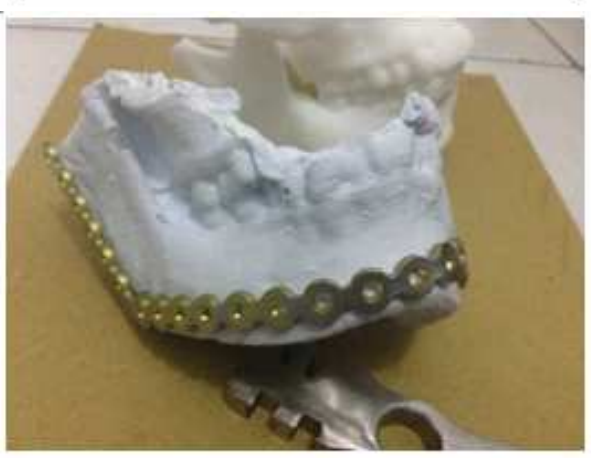

Gambar 20. Prekontur plat rekonstruksi preoperatif (kasus 3)

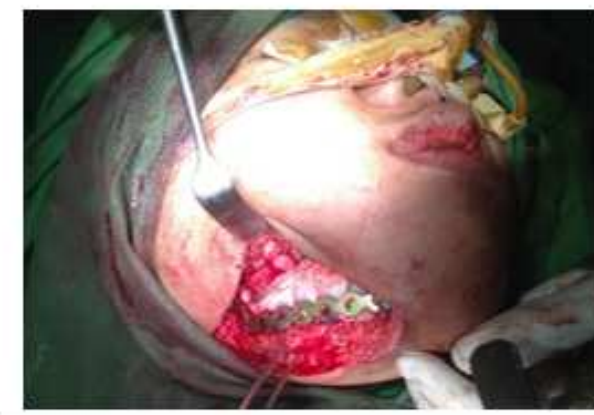

Gambar 22. Autobonegraft illiaka (kasus 3)

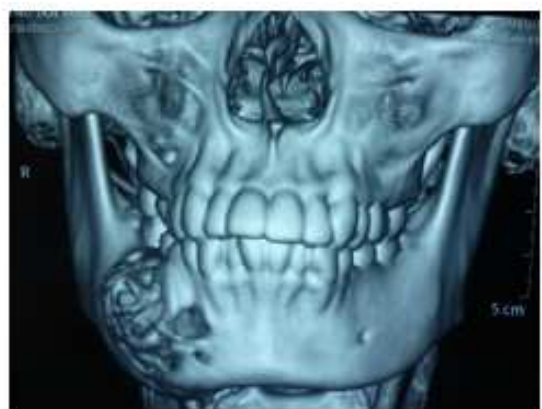

Gambar 19. foto CT scan dengan gambaran soap bubble aperance (kasus 3 )

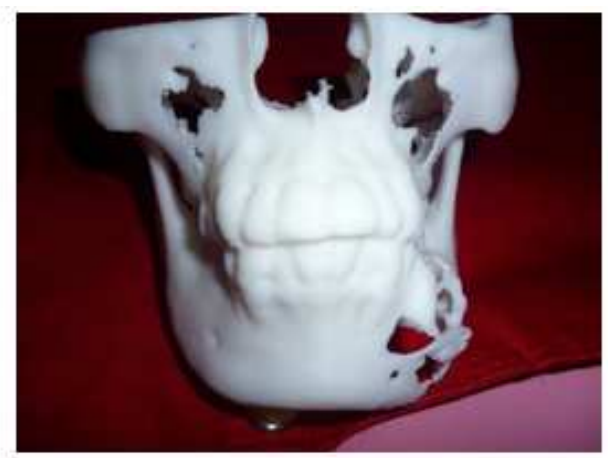

Gambar 21. MRP dengan metode mirroring transposisi letak tumor (kasus 3)

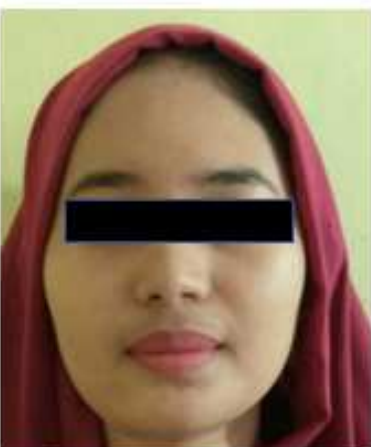

Gambar 23. Klinis ekstra oral pasca operasi 3 tahun (kasus 3)

graft yang baik dengan tulang mandibula yang sehat (gambar 25).

\section{HASIL}

Pembentukan plat rekonstruksi menggunakan MRP (medical rapid prototyping) dengan prosedur CAD/CAM (computer-aided design and computer aided manufacture) 


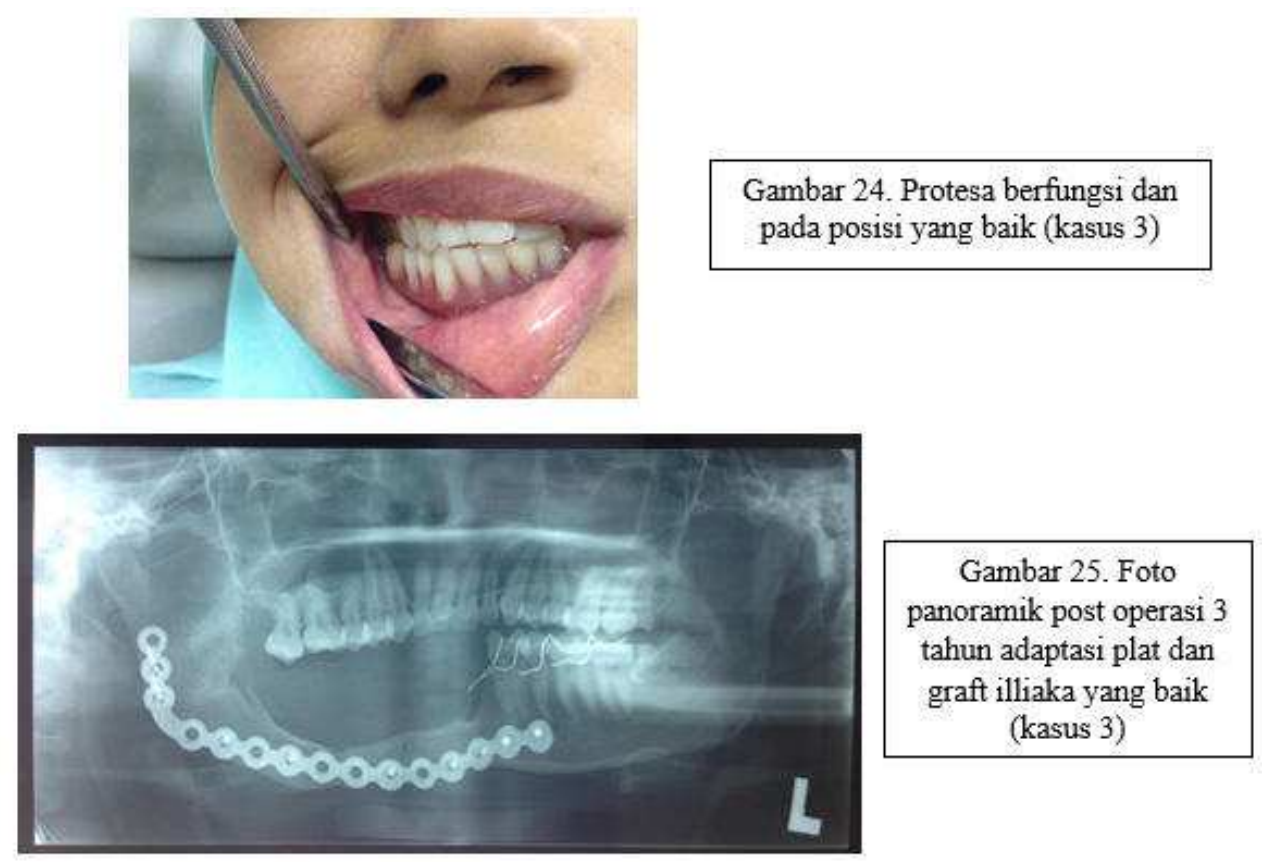

memberikan hasil sesuai dengan bentuk aslinya.

\section{DISKUSI}

Berdasarkan pengalaman kami dari ketiga kasus diatas, model MRP membantu untuk media simulasi sebelum pembedahan dengan timoperasi, Modelinidapatjugadigunakanuntuk menjelaskan dan berdiskusi dengan pasien mengenai penyakit serta perluasan tumor yang diderita. Ini akan memberikan pemahaman yang lebih baik pada mereka mengenai proses yang akan dijalankan, dan hasil yang diharapkan. Pada kasus 3 kami merencanakan membuat 1 model MRP yang berfungsi untuk alat bantu prekontur plat rekonstruksi serta membantu dalam menjelaskan penyakit, dan rencana pembedahan kepada pasien. Kami memutuskan perencanaan teknik virtual dengan metode mirorring untuk transposisi tumor dimana letak tumor pada corpus mandibula dextra, kami lakukan transposisi pada corpus mandibula sinistra.
Penurunan waktu operasi dengan menggunakan metode ini cukup signifikan karena kami tidak perlu mengadaptasikan plat rekonstruksi intraoperatif yang telah di prekontur. Ini sesuai dengan penelitian Toro dkk8 pada 24 pasien. Mereka melaporkan waktu pembedahan berkurang sekitar 1.5 jam dibandingkan prosedur pembedahan reseksi konvensional. Pembuatan model stereolithography serta penggunaannya untuk model preoperatif dapat menurunkan waktu operasi dan kesulitan operasi bedah rekonstruksi mandibula.

Pengurangan gips biru untuk prekontur plat rekonstruksi saat preoperatif pada regio tulang bukal dan labial yang direseksi pada semua kasus dan meletakkan $1 \mathrm{~cm}$ diatas margo inferior mandibula pada sisi hemimandibulektomi (kasus 1) berfungsi untuk menghindari penonjolan plat rekonstruksi yang dapat menganggu suplai darah disekitar jaringan lunak yang selanjutnya menimbulkan scar yang kurang baik bahkan menyebabkan komplikasi seperti terbukanya plat ke bagian 
ekstraoral atau intra oral. Yamada dkk. ${ }^{9}$ menyebutkan apabila plat digunakan pada daerah simfisis, maka plat harus under contured untuk menghindari proyeksi berlebihan pada daerah pogonion. Hal ini didukung oleh pendapat Okura dkk. ${ }^{10}$ yang menyebutkan dehisensi ekstra oral disebabkan karena adanya dead space di sekitar plat rekonstruksi. Jaringan lunak yang menutupi plat sangat tipis dan perbandingan lebar plat dengan jaringan lunak yang menutupi plat tidak seimbang yang menyebabkan vaskularisasi minimal pada daerah plat sehingga mengakibatkan iskemik pada jaringan berpotensi terjadi dehisensi jaringan. Untuk meminimalkan terjadinya hal ini salah satunya dengan prekontur plat rekonstruksi sebelum operasi. Ketebalan pengurangan gips yang dibutuhkan kami sesuaikan dengan ketebalan plat rekonstruksi yang akan digunakan. Pada kasus 1 , model MRP juga membantu kami dalam simulasi mengukur jarak vertikal dari insisal gigi molar 1 rahang atas ke daerah margo inferior mandibular. Hal ini sangat membantu kami saat intraoperatif sebagai panduan dalam mengontrol letak plat rekonstruksi daerah posterior pada kasus hemimandibulektomi.

Saat prekontur plat rekonstruksi preoperatif pada kasus 2 dan kasus 3 yang dilakukan reseksi segmental mandibula pada daerah ramus perlu diperhatikan letak plat dari coen's ramus fixator pada saat intraoperatif. Hal ini agar plat dari coens ramus fixator tidak menyentuh plat rekonstruksi yang di prekontur sehingga dapat menyebabkan celah antara tulang mandibula yang sehat dengan plat rekonstruksi yang berpotensi terjadinya dead space dan scar (gambar 16). Pada kasus 2 dan 3 rehabilitasi mandibula menggunakan graft tulang cortico cancelous autogenus avaskuler dari tulang illika untuk membantu terbentuknya kontinuitas dan kekuatan rahang yang dibutuhkan, agar berfungsi normal dengan rehabilitasi menggunakan protesa (Gambar 24).

Coen's ramus fixator dipasang pada kasus 2 dan kasus 3 sebagai alat bantu untuk memandu penempatan plat rekonstruksi titanium dan graft tulang illiaka cortico cancelous, sehingga mempunyai relasi dan oklusi yang tepat dengan maksila serta menjaga sisa ramus mandibula tetap pada tempatnya saat akan dipasang plat rekonstruksi ${ }^{11}$.

Perencanaan teknik virtual dengan prosedur CAD/CAM cukup membantu untuk mencapai rekonstruksi yang adekuat, dapat memperhitungkan deglutinasi, mastikasi, cara bicara dan juga perencanaan protesa pasca operasi pada pasien. Teknik perencanaan virtual membutuhkan pengetahuan dari ahli komputer yang berpengalaman dengan kemampuan sensasi haptic yang memadai, sehingga membutuhkan penambahan waktu dan biaya pre operatif. Hal ini bertujuan untuk mengoptimalkan perawatan. Walaupun begitu kami menyarankan penggunaannya dalam rekonstruksi mandibula karena memberikan banyak keuntungan. Dokter bedah akan mendapatkan cetakan perluasan reseksi dan rekonstruksi yang dibutuhkan dengan lebih baik.

Prekontur plat rekonstruksi titanium menggunakan model MRP sangat efektif, efisien dan akurat tanpa perlu berkali - kali melakukan pembengkokan. Widiastuti dkk. ${ }^{11}$ menjelaskan plat rekonstruksi titanium memiliki sifat biokompatibel yang baik tapi bahan titanium memiliki sifat modulus elastisitas yang rendah sehingga rawan rapuh dan susah untuk dibentuk. Pada permukaan dalam lengkung plat rekonstruksi merupakan tempat awal terjadinya keretakan, akibat konsentrasi 
stress pada bahu dari potongan plat yang tipis pada waktu pembentukan plat, sehingga timbul residual stress yang menyebabkan kelelahan pada plat. Beban pengunyahan akan menambah keretakan pada plat sehingga terjadi fraktur plat rekonstruksi.

Pasien yang direncanakan rekonstruksi dengan alat bantu MRP memiliki hasil wajah cukup simetri pada pemeriksaan klinis post operasi sehingga memberikan hasil akhir yang estetika. Ini sesuai dengan penelitian yang dilakukan oleh Azuma dkk. ${ }^{5}$ yang mengatakan, sudut diferensial pasien yang menggunakan MRP lebih kecil dibandingkan dengan pasien dengan grup teknik konvensional. Hal ini menunjukkan kontur simetri pada mandibula grup MRP lebih baik. Cohen ${ }^{4}$ menyampaikan tujuan rekonstruksi adalah menjaga estetik dan simetri wajah yang baik serta mendapatkan hasil akhir fungsional yang baik, dapat menjaga bentuk dan kekuatan rahang sehingga memudahkan rehabilitasi gigi selanjutnya.

\section{KESIMPULAN}

Pembuatan MRP melalui prosedur CAD/ CAM memberikan hasil maksimal menyerupai bentuk model mandibula. Model MRP mendapatkan gambaran rahang pasien yang akurat sebagai alat bantu prekontur plat rekonstruksi. Pembentukan plat rekonstruksi (prekontur) dengan model MRP ini didapat dari CAD/CAM dan memberikan gambaran rahang normal, sehingga prekontur preoperatif akan memberikan hasil yang baik dan maksimal pada plat rekonstruksi yang dibuat berdasarkan model MRP.

\section{UCAPAN TERIMA KASIH}

Ucapan terima kasih sebesar - besarnya ditujukan kepada drg. Maria Goreti Widiastuti,
Sp.BM(K) yang telah memberi dukungan dan arahan dalam penulisan naskah ini.

\section{DAFTAR PUSTAKA}

1. Salguiero M I, Stevens M R, 2010. 'Experience with the use of prebent plates forthe reconstruction of mandibular defects'. Craniomaxillofacial Trauma Reconstruction. Vol.3 (4), pp. 201 - 208

2. Pramono Coen, 2008, 'Coen's ascending ramus fixator use for repositioning the ascending ramus during mandible reconstruction'. Dent. J. (Maj. Ked. Gigi), Vol. 41. No. 1 January-March H: 10-14.

3. Hannen E J M, 2006. 'Recreating the original contour in tumor deformed mandibles for plate adapting', Int. J. Oral Maxillofac. Surg. Vol.35. 183-185.

4. Cohen A, Laviv A, Berman P, Nashef R, AbuTair J, 2009, 'Mandibular Reconstruction using stereolithography 3-dimensional printing modeling technology', Oral Surgery, Oral Medicine, Oral Pathology, Oral Radiology, And Oral Endotology. vol. 108,(5), pp. 661-666

5. Azuma M et all. 2011, 'Mandibular reconstuction using plates prebent to fit rapid prototyping 3-dimensional printing models ameliorates contour deformity', J Head \& Face Medicine. vol.10,(45), pp.1-8

6. Lethaus B, Poort L, Bockmann R, Smeets R, Tolba $R$, Kessler $P, 2011$, 'Additive manufacturing for microvascular reconstruction of the mandible in 20 patients', J cranio-Maxillo-facial Surgery, vol. 40, pp.43-46

7. Kermer C, 1999, 'Preoperative stereolithoraphy model planning in craniomaxillofacial surgery'. Computed Assisted Surgery. Vol.2, pp. 1-3

8. Toro C, Robiony M, Costa F, Zerman N, Politi M, 2007, 'Feasibility of preoperative planning using anatomical facsimile model mandibular reconstruction'. J Head \& Face Medicine, Vol. 3(5). pp.1-11

9. Yamada $\mathrm{H}$, Ishihama $\mathrm{K}$, Yasuda K, Nakayama YH. Okayama M, Yamada T, Furusawa K, 2010. 'Precontured mandibular plate with threedimensional model significantly shortened the mandibular reconstruction time'. Asian Journal Of Oral And Maxillofacial Surgery, vol 22. Pp 198- 201

10. Okura M, Isomura E T, Lida S, Kogo M, 2005, 'Longterm outcome and factors influencing bridgingplats for mandibular reconstruction' J oral oncology, vol. 41, pp. 791-798

11. Widiastuti MG, Pascawinata A, 2013. 'Pengunaan model anatomi mandibula 3 dimensi pada operasi reseksi dan rekonstruksi mandibula'. Seminar nasional AKSI KG II, pp. 105-120 